\title{
Impedance flow cytometry for viability analysis of Corynebacterium glutamicum
}

Hartmann, Fabian Stefan Franz; Anastasiou, loannis; Weiß, Tamara; Shen, Jing; Seibold, Gerd Michael

Published in:

Journal of Microbiological Methods

Link to article, DOI:

10.1016/j.mimet.2021.106347

Publication date:

2021

Document Version

Peer reviewed version

Link back to DTU Orbit

Citation (APA):

Hartmann, F. S. F., Anastasiou, I., Weiß, T., Shen, J., \& Seibold, G. M. (2021). Impedance flow cytometry for viability analysis of Corynebacterium glutamicum. Journal of Microbiological Methods, 191, [106347]. https://doi.org/10.1016/j.mimet.2021.106347

\section{General rights}

Copyright and moral rights for the publications made accessible in the public portal are retained by the authors and/or other copyright owners and it is a condition of accessing publications that users recognise and abide by the legal requirements associated with these rights.

- Users may download and print one copy of any publication from the public portal for the purpose of private study or research.

- You may not further distribute the material or use it for any profit-making activity or commercial gain

- You may freely distribute the URL identifying the publication in the public portal 


\section{Journal Pre-proof}

Impedance flow cytometry for viability analysis of Corynebacterium glutamicum

Fabian Stefan Franz Hartmann, Ioannis Anastasiou, Tamara Weiß, Jing Shen, Gerd Michael Seibold

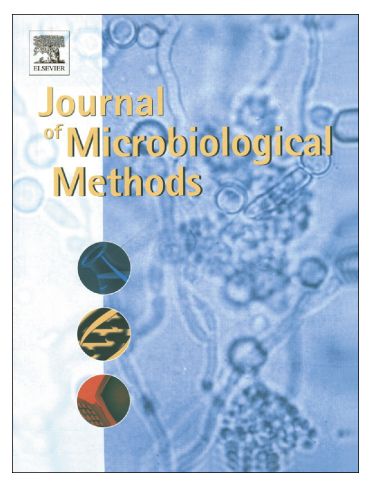

S0167-7012(21)00215-3

https://doi.org/10.1016/j.mimet.2021.106347

MIMET 106347

Journal of Microbiological Methods

Received date:

23 September 2021

Revised date:

12 October 2021

Accepted date:

Please cite this article as: F.S.F. Hartmann, I. Anastasiou, T. Weiß, et al., Impedance flow cytometry for viability analysis of Corynebacterium glutamicum, Journal of Microbiological Methods (2021), https://doi.org/10.1016/j.mimet.2021.106347

This is a PDF file of an article that has undergone enhancements after acceptance, such as the addition of a cover page and metadata, and formatting for readability, but it is not yet the definitive version of record. This version will undergo additional copyediting, typesetting and review before it is published in its final form, but we are providing this version to give early visibility of the article. Please note that, during the production process, errors may be discovered which could affect the content, and all legal disclaimers that apply to the journal pertain.

C 2021 Published by Elsevier B.V. 


\title{
Impedance flow cytometry for viability analysis of Corynebacterium glutamicum
}

\author{
Fabian Stefan Franz Hartmann ${ }^{1}$, loannis Anastasiou ${ }^{1}$, Tamara Weiß ${ }^{1}$, Jing Shen ${ }^{1}$, and Gerd Michael \\ Seibold ${ }^{1}$
}

\footnotetext{
${ }^{1}$ Department of Biotechnology and Biomedicine, Section for Synthetic Biology, Technical University of Denmark, Kongens. Lyngby, Denmark
}

Correspondence: Gerd M. Seibold, Section of Synthetic Biolo $y$, L epartment of Biotechnology and Biomedicine, Technical University of Denmark, Søltofts Plads 3uilü.ıg 223, DK-2800, Kongens Lyngby, Denmark; e-mail: gesei@dtu.dk

Running title: Impedance flow cytometry for C. gluter, $i$. ur

Article type: Brief communication

Key Words: Corynebacterium gl'itu. nicum, viability, cell wall inhibitor, penicillin, glutamate production, impedance flow cytometry 


\begin{abstract}
Corynebacterium glutamicum efficiently produces glutamate when growth is inhibited. Analyses of viability in this non-growing state requires time consuming plating and determination of colony forming units. We here establish impedance flow cytometry measurements to assess the viability of non-growing, glutamate producing $C$. glutamicum cultures within minutes.
\end{abstract}

\title{
INTRODUCTION
}

Biomass and viability are key parameters in cultivation ${ }_{2}$ roiesses and different techniques have been developed for on-line or in-situ measurements of th -e two variables (Olsson and Nielsen, 1997; Reichelt et al., 2016). They are common y w «ssed by measuring changes of the optical density (OD), cell dry weight (CDW), to ${ }^{\prime} 1$ cell numbers (colony forming units (CFU)), livedead-staining using fluorescent dyes ¿* metabolic activity (e.g. offgas analyses of $\mathrm{CO}_{2}$ formation and $\mathrm{O}_{2}$ consumption, $a_{0} l_{l, u}$ analyses of substrate and product concentrations). Impedance flow cytometry (IFC, via microfluidic sensors was initially developed to accurately assess bacteria levels in d in' inz water in real-time (Clausen et al., 2018) and to detect pathogens (Furst and Francis, 2019). The technology was described to be able to detect all types of bacteria and to distinguish them from particles and dead cells based on their electrical properties (Clausen et al., 2018; Furst and Francis, 2019). Additionally, it is considered as a novel tool to quickly assess viability of bacteria during bench-scale cultivations as well as industrial fermentations (Bertelsen et al., 2020; David et al., 2012).

The Gram-positive bacterium C. gutamicum is used for large scale industrial production of amino acids (Eggeling and Bott, 2015) and has been engineered into a versatile platform 
organism for the production of fine and bulk chemicals from renewable feedstocks (Wolf et al., 2021). Determining the cellular fitness of C. glutamicum during glutamate production has limitations as glutamate secretion is triggered by conditions disturbing cell wall and/or membrane integrity (Eggeling et al., 2001; Radmacher et al., 2005). Thus, glutamate producing cultures of C. glutamicum consist of non-growing but optimally viable and active cells, a physiological state which cannot easily be assessed via simple biomass measurements.

In this communication we investigate the use of a recently devel $r_{\mathbf{Y}} \mathrm{d}$, hand held multi-frequency IFC device for the analysis of the viability of $C$. glutamicun $\imath$ ch'tures in different physiological states. We compare IFC measurements with analyses of $\mathcal{C}^{\mathrm{q}} \mathcal{L}$ and finally analyze the viability of C. glutamicum cells during penicillin induced glutama ${ }^{\dagger}$ pru duction.

\section{MATERIALS \& METHODS}

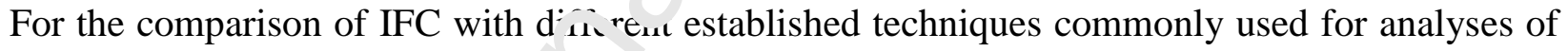
C. glutamicum viability, the vilu type strain C. glutamicum ATCC13032 (Abe et al., 1967) was cultivated in $50 \mathrm{~mL} 2 \mathrm{xTY}_{-1 \mathrm{r}}{ }^{\circ}$ aium $\left(16 \mathrm{~g} / \mathrm{L}\right.$ Yeast extract; $10 \mathrm{~g} / \mathrm{L} \mathrm{NaCl} ; 5 \mathrm{~g} / \mathrm{L}$ Tryptone) at $30^{\circ} \mathrm{C}$ in baffled shaker flasks. amples of exponentially growing (3- 4 hours prior inoculation which corresponds to an OD of 2-3) C. glutamicum cells were harvested by centrifugation (10 min.; $2750 \mathrm{xg}$ ), washed once with saline $(0.9 \mathrm{~g} / \mathrm{L} \mathrm{NaCl})$, and incubated for $30 \mathrm{~min}$. (room temperature; $150 \mathrm{rpm})$ with either saline to preserve living cells or $70 \%(\mathrm{v} / \mathrm{v})$ isopropyl alcohol to obtain dead cells (Seibold et al., 2009). Subsequently, the treated cells were pelleted (10 min; $2750 \mathrm{x} \mathrm{g}$ ) and then re-suspended in saline. Cell suspensions were plated on 2xTY-agar plates and incubated for $48 \mathrm{~h}$ at $30^{\circ} \mathrm{C}$. IFC measurements of bacterial viability using the BactoBox (SBT 
instruments, Herlev, Denmark) were conducted using Flow Impendance Buffer (FIB) (dissolved in MilliQ water: $7 \mathrm{mM} \mathrm{NaCl} ; 0.14 \mathrm{mM} \mathrm{KCl} ; 0.5 \mathrm{mM} \mathrm{Na}_{2} \mathrm{HPO}_{4} ; 0.09 \mathrm{mM} \mathrm{KH}_{2} \mathrm{PO}_{4}$; $\mathrm{pH}$ adjusted to 7.4 using $2 \mathrm{M} \mathrm{HCl}$; conductivity below $700-900 \mu \mathrm{S}$ at $20^{\circ} \mathrm{C}$ ).

Growth of C. glutamicum in CGXII minimal medium (Graf et al., 2018) with $1 \%$ (w/v) glucose as sole carbon source was performed in a BioLectorII system (m2p-labs, Baesweiler, Germany) using 48-well Flowerplates (m2p-labs) as $800 \mu \mathrm{L}$ cultures with an initial OD of 3 at $1500 \mathrm{rpm}$ and $30^{\circ} \mathrm{C}$ as recently described (Hemmerich et al., 2019).

\section{RESULTS \& DISCUSSION}

For C. glutamicum cell suspensions in $\cdots^{\prime}$ 'sated with saline a CFU of $3.0 \times 10^{8} \pm 9.2 \times 10^{6} \mathrm{CFU} / \mathrm{mL}$ was determı. r. In contrast, no CFU was detected when isopropyl alcohol treated cells were plated (Fig. 1a, When plating mixtures of both suspensions, the CFU

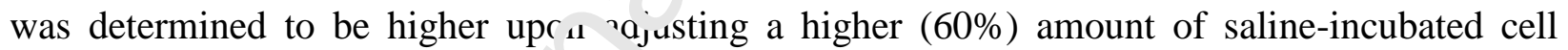
suspension in the respective mix.re, whereas it was vice versa when applying a lower amount (40\%) (Fig. 1a). This shr $w_{\sim}$ that by mixing the differently pretreated cell suspension, mixtures containing a defined ratio of viable and dead cells can accurately be set.

IFC measurements of bacterial viability require a low ionic strength of the buffer used to prepare the suspension (Clausen et al., 2018; David et al., 2012). Therefore, FIB as an alternative to saline to suspend C. glutamicum cells was tested. Upon incubation of C. glutamicum cells for 30 min. with either saline or FIB, the CFU was determined to be $1.33 \times 10^{8} \pm 4.55 \times 10^{6}$ and $1.24 \mathrm{x}$ $10^{8} \pm 4.68 \times 10^{6}$, respectively, which was analyzed to be not significantly different $(\mathrm{p}=0.07)$ (Fig. 1b). 
a
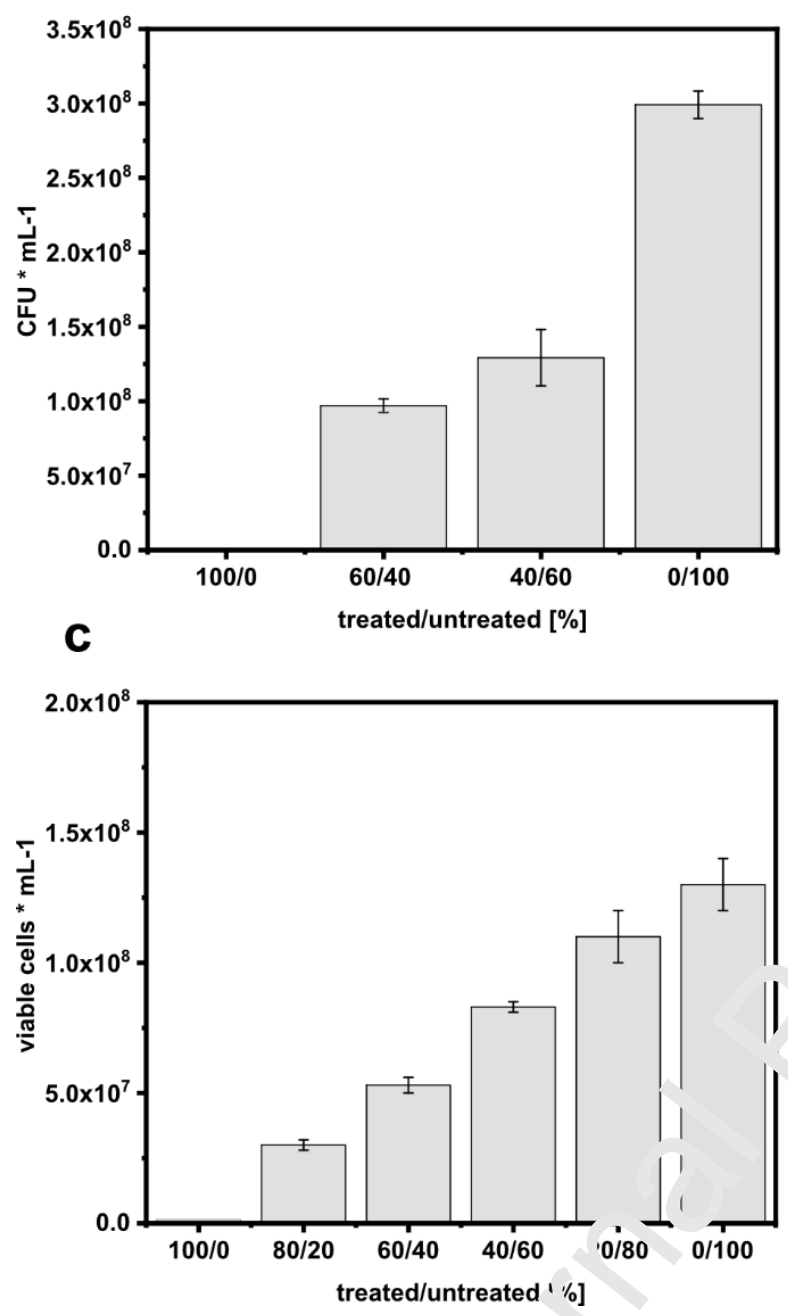

b

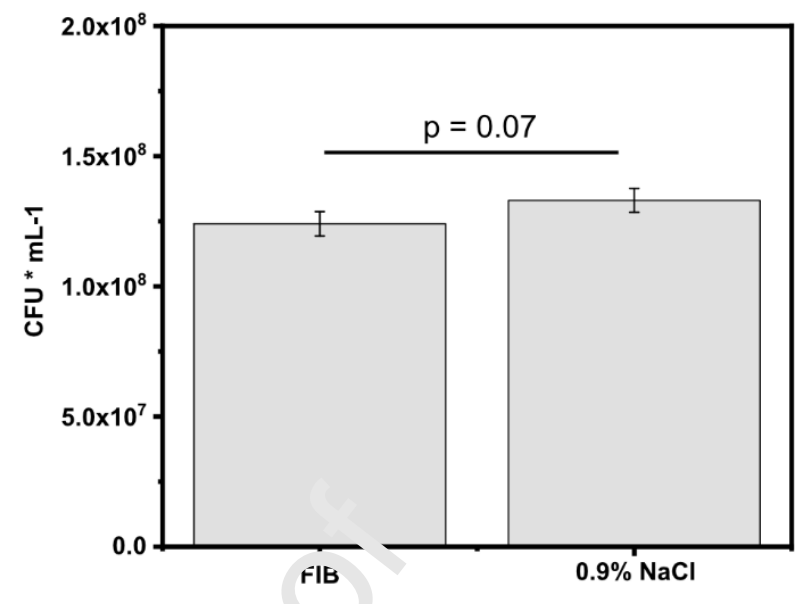

d

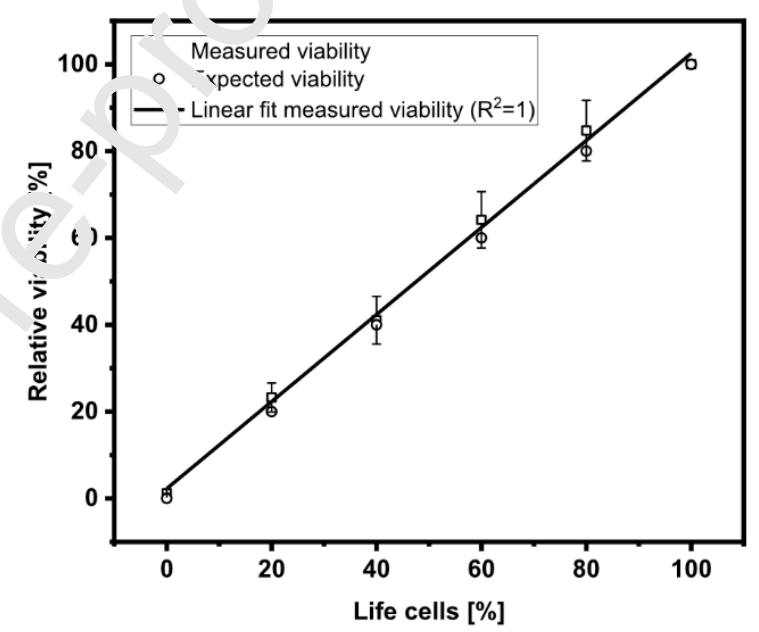

Figure 1: Viability measu. $n_{n},{ }^{n} . s$ of $C$. glutamicum cultures via different methods. Colony forming units (CFU) were determined for cultures treated with isopropyl alcohol (treated) or saline (untreated) and different mixtures of both types of cultures (a). CFU numbers determined and compared for C. glutamicum cultures suspended in flow impedance buffer (FIB) or saline (b). Determination of viable cells via impedance flow cytometry (IFC) for C. glutamicum cultures treated with isopropyl alcohol (treated) or saline (untreated) and different mixtures of both (c). Linear regression curve of measured relative cell viability using IFC and expected relative viabilities for the different prepared culture mixtures (d). One-way ANOVA with Tukey's test was performed to assess the significance of difference 
between CFU numbers for C. glutamicum cultures suspended in different buffers. Numbers were determined to be not significantly different ( $p<0.05$ is considered as significantly different). Error bars represent standard deviation from at least three replicates.

When suspensions of defined amounts of dead and viable C. glutamicum cultures were analyzed via IFC, $1.3 \times 10^{8} \pm 1.0 \times 10^{7}$ viable cells $/ \mathrm{mL}$ were detected for $\mathrm{nr} \mathrm{n}$-treated cells (Fig. $\left.1 \mathrm{c}\right)$, which is in the same range of the number of CFU determined for $\mathrm{F}^{\prime} \mathrm{B}$ s 'spensions as well as saline diluted cells (see above). The number of viable cells ditect d via IFC in the suspension decreased when the mixtures contained isopropyl alcot ol $\iota$ eated cells (Fig. 1c). Indeed, a linear correlation $\left(\mathrm{R}^{2}=1\right)$ between the percentage of livin; cells in the defined suspensions and the relative viability measured via IFC was $\mathrm{d}_{\ldots}^{\prime .} \cdot \mathrm{n}_{\llcorner}$ned (Fig. 1d). The results indicate that IFC is well suited to analyze viability of $C$. glutamı 'm cells in suspensions containing both viable and non-viable cells.

The addition of Penicillin inh oits growth of C. glutamicum and in turn triggers glutamate production (Eggeling et al., 200 ). Effects of Penicillin G (PenG) (0- $1000 \mathrm{U} / \mathrm{mL})$ on growth of C. glutamicum were tes ${ }^{2} \mathrm{a}:-$ a BioLectorII system for 22 hours. As depicted in Fig. 2a, varying the PenG concentration between 0 and $1000 \mathrm{U} / \mathrm{mL}$ affected growth and final biomass of C. glutamicum. Growth of C. glutamicum ceased from a growth rate of $0.17 \pm 0.01 \mathrm{~h}^{-1}$ in absence of PenG to a growth rate of $0.01 \pm 0.01 \mathrm{~h}^{-1}$ for concentrations above $1 \mathrm{U} / \mathrm{mL}$ (Fig. 2b). To confirm glutamate production by non-growing $C$. glutamicum strains, a glutamate assay was performed according to the manufacturer's instructions (Megazyme, Ireland). As expected, glutamate production was decoupled from growth, resulting in a final titer of $0.03 \pm 0 \mathrm{~g} / \mathrm{L}$ glutamate in absence or presence of low PenG concentrations, but increased in presence of > 
$1 \mathrm{U} / \mathrm{mL}$ PenG (Fig. $2 \mathrm{~b}$ ) to titers of up to $0.47 \pm 0.01 \mathrm{~g} / \mathrm{L}$ after $22 \mathrm{~h}$ of cultivation. The formation of glutamate by the cultures in presence of more than $1 \mathrm{U} / \mathrm{mL}$ PenG indicates that despite the fact that no biomass formation was observed, active cells were present. Indeed, the viability measurements via plating and CFU determination (Fig 2c) as well as via IFC (Fig. 2d) confirmed that even at a concentration of $1000 \mathrm{U} / \mathrm{mL}$ PenG, viable cells are present in the $C$. glutamicum cultures. In detail for cells treated with $0.1 \mathrm{U} / \mathrm{mL}$ PenG $2.88 \times 10^{7} \pm 2.9 \times 10^{6} \mathrm{CFU} * \mathrm{~mL}^{-1} *$ $\mathrm{OD}_{600 \mathrm{~nm}}{ }^{-1}$ and $1.31 \times 10^{8} \pm 7.66 \times 10^{6}$ viable cells $* \mathrm{~mL}^{-1} * \mathrm{OD}_{600 \mathrm{~mm}}{ }^{1}$ were determined via plating and IFC, respectively. This
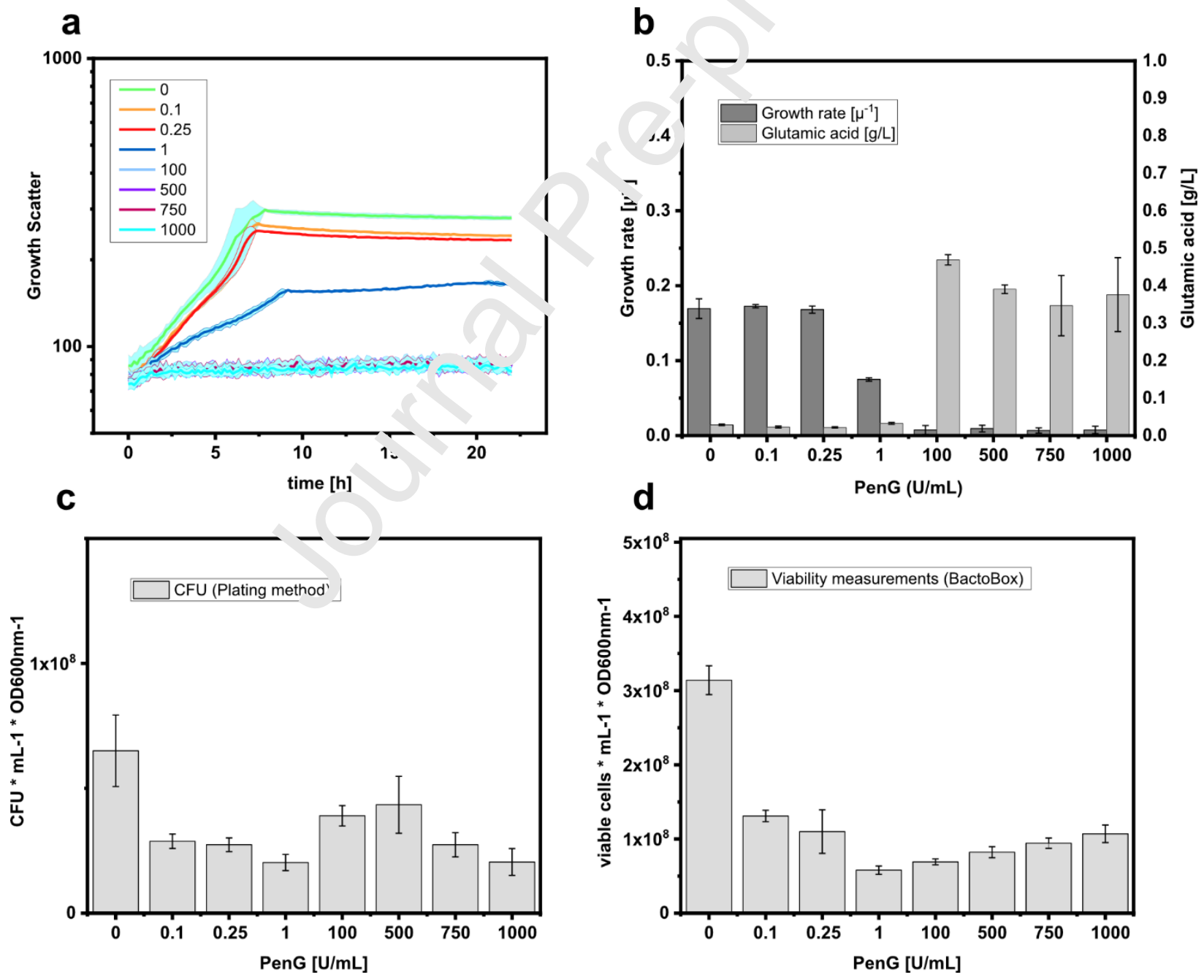
corresponds to $46 \pm 15 \%$ and $42 \pm 5 \%$ of the total cell numbers determined for non-PenG treated cultures via plating and IFC, respectively. With higher PenG concentration the relative cell viability determined via the two different methods remained approximately between $30 \%$ $45 \%$ for most approaches. This fits to the observation that in presence of high PenG concentrations cells were in a non-growing but producing state. To note, higher absolute cell numbers were determined via IFC when compared to $\mathrm{CFU}$ (plating) (Fig. 2c, d). This observation might indicate that cultures under these condit.vi.s contained viable but not culturable cells (Oliver, 2005), as it has been reported for $C$ glitamicum cadaverine-production strains (Olughu et al., 2020).

Figure 2: Growth of C. glutamicum in minimal meriun.I (CGXII) at different set Penicillin G (PenG) concentrations (0-1000 U/mL) (a), growth ra+ ${ }^{+} \mathrm{s}$ mn i final glutamate titers in the cultures supernatant when growing in presence of different PenG conc ntrations (b) and the final cell viability determined via plating (c) and by impedance flow cytor 2t' ${ }^{\prime}(1+C)$ using the BactoBox (d). Cultivation was performed in a BioLectorll system (m2p-labs, Baesw iler/ DE) using 48-well Flowerplates (m2p-labs, Baesweiler/DE) and $800 \mu \mathrm{L}$ cultures at $1500 \mathrm{rpm}$ and $\mathrm{\supset}^{\circ} \mathrm{C}$ with $1 \%(\mathrm{w} / \mathrm{v})$ glucose as sole carbon source. Error bars represent standard deviation from bi logi al triplicates.

Taken together, the results show that IFC allows fast analyses of the cellular viability of C. glutamicum. The procedure, including sampling and analysis, takes no longer than five minutes to determine the viability of a cell culture. This is crucial for fast decision-making for processes involving non-growing but producing strains.

\section{AUTHOR'S CONTRIBUTION}


Fabian Stefan Franz Hartmann: Conceptualization, Investigation, Data curation, Methodology, Visualization, Formal analysis, Validation, Writing- Original draft, Review \& Editing

Ioannis Anastasiou: Investigation, Data curation, Formal analysis, Validation

Tamara Weiß: Investigation, Methodology, Writing- Review \& Editing

Jing Shen: Methodology, Writing- Review \& Editing

Gerd Michael Seibold: Conceptualization, Methodology, Supervision, Writing- Original draft, Review \& Editing

\section{CONFLICT OF INTEREST}

The authors declare that the research was conducted in the a'sence of any commercial or financial relationships that could be construed as a pote itial conflict of interest.

\section{ACKNOWLEDGEMENTS}

We would like to thank the Fermentation C ce at DTU Bioengineering for excellent technical support and Gustav E. Skands and Micn.el Maimann of SBT Instruments A/S for very helpful discussions.

\section{FUNDING}

This work was funded $b$, the Novo Nordisk Fonden within the framework of the Fermentationbased Biomanufacturing suitiative (FBM) (FBM-grant: NNF17SA0031362).

\section{REFERENCES}

Abe, S., Takayama, K.I., Kinoshita, S., 1967. Taxonomical studies on glutamic acid-producing bacteria. J. Gen. Appl. Microbiol. 13, 279-301.

Bertelsen, C.V., Franco, J.C., Skands, G.E., Dimaki, M., Svendsen, W.E., 2020. Investigating the use of impedance flow cytometry for classifying the viability state of E. coli. Sensors. 20, $1-16$.

Clausen, C.H., Dimaki, M., Bertelsen, C.V., Skands, G.E., Rodriguez-Trujillo, R., Thomsen, J.D., Svendsen, W.E., 2018. Bacteria detection and differentiation using impedance flow 
cytometry. Sensors. 18, 1-12.

David, F., Hebeisen, M., Schade, G., Franco-Lara, E., Di Berardino, M., 2012. Viability and membrane potential analysis of Bacillus megaterium cells by impedance flow cytometry. Biotechnol. Bioeng. 109, 483-492.

Eggeling, L., Bott, M., 2015. A giant market and a powerful metabolism: 1-lysine provided by Corynebacterium glutamicum. Appl. Microbiol. Biotechnol. 99, 3387-3394.

Eggeling, L., Krumbach, K., Sahm, H., 2001. L-glutamate efflux with Corynebacterium glutamicum: Why is penicillin treatment or tween addition doing the same? J. Mol. Microbiol. Biotechnol. 3, 67-68.

Furst, A.L., Francis, M.B., 2019. Impedance-based detection of $t$ anteria. Chem. Rev. 119, 700726.

Graf, M., Zieringer, J., Haas, T., Nieß, A., Blombach, B T.1.rs, R., 2018. Physiological response of Corynebacterium glutamicum to increasin ${ }^{\text {rly }} 1$ utrient-rich growth conditions. Front. Microbiol. 9, 1-15.

Hemmerich, J., Tenhaef, N., Steffens, C., Kappelmat. J. Weiske, M., Reich, S.J., Wiechert, W., Oldiges, M., Noack, S., 2019. Less sacrif'ce, nore insight: Repeated low-volume sampling of microbioreactor cultivations ena $1 f_{s}$ accelerated deep phenotyping of microbial strain libraries. Biotechnol. J. 14, 1800428

Oliver, J.D., 2005. The viable but noncultı "ar e state in bacteria. J. Microbiol. 43, 93-100.

Olsson, L., Nielsen, J., 1997. On-lı, $\cdot 0$ and in situ monitoring of biomass in submerged cultivations. Trends Biotechnol. 1 $5.7-522$.

Olughu, W., Nienow, A., Hewitt, C. h:-lly, C., 2020. Scale-down studies for the scale-up of a recombinant Corynebacteriur. glutamicum fed-batch fermentation: loss of homogeneity leads to lower levels of cada' 'erine production. J. Chem. Technol. Biotechnol. 95, 675-685.

Radmacher, E., Stansen, K.`. Besra, G.S., Alderwick, L.J., Maughan, W.N., Hollweg, G., Sahm, H., Wendis h, I.F., Eggeling, L., 2005. Ethambutol, a cell wall inhibitor of Mycobacterium tu 'rculosis, elicits L-glutamate efflux of Corynebacterium glutamicum. Microbiology 151, 1:59-1368.

Reichelt, W.N., Thurrold, P., Brillmann, M., Kager, J., Fricke, J., Herwig, C., 2016. Generic biomass estimation methods targeting physiologic process control in induced bacterial cultures. Eng. Life Sci. 16, 720-730.

Seibold, G.M., Wurst, M., Eikmanns, B.J., 2009. Roles of maltodextrin and glycogen phosphorylases in maltose utilization and glycogen metabolism in Corynebacterium glutamicum. Microbiology 155, 347-358.

Wolf, S., Becker, J., Tsuge, Y., Kawaguchi, H., Kondo, A., Marienhagen, J., Bott, M., Wendisch, V.F., Wittmann, C., 2021. Advances in metabolic engineering of Corynebacterium glutamicum to produce high-value active ingredients for food, feed, human health, and wellbeing. Essays Biochem. 65, 197-212. 


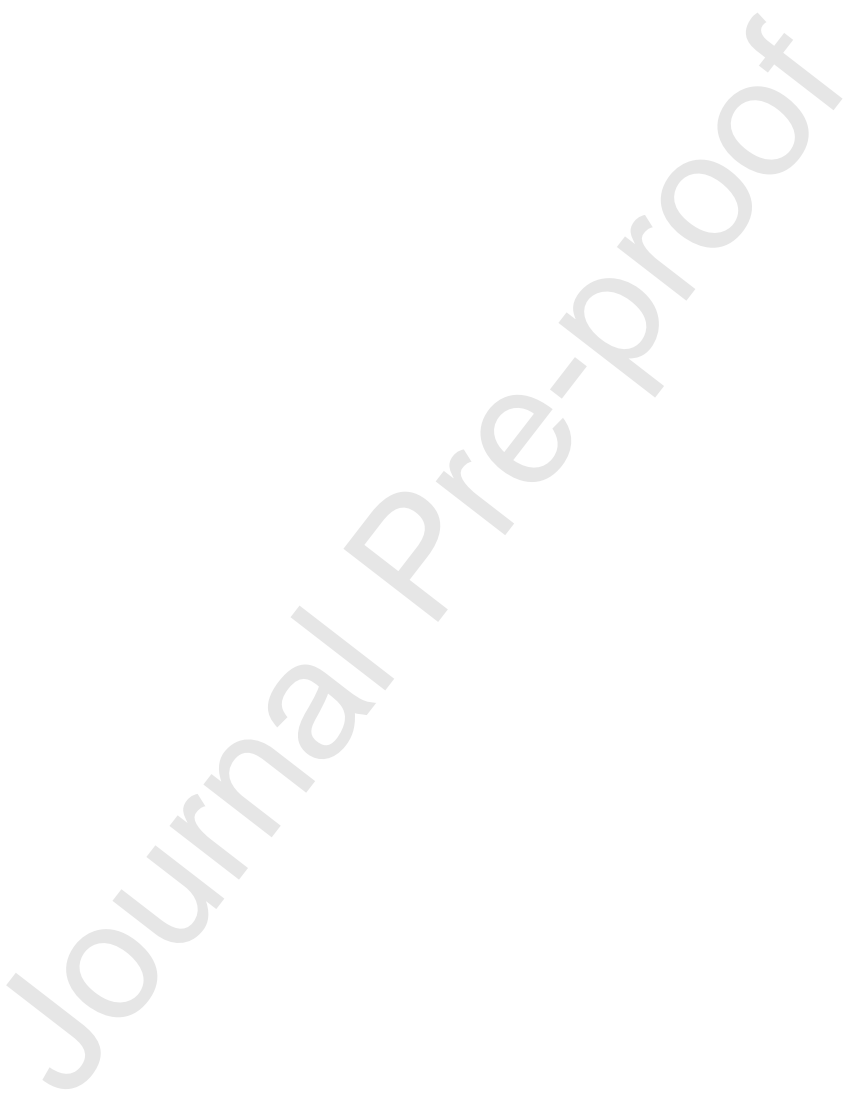


Highlights of the manuscript "Impedance flow cytometry for viability analysis of Corynebacterium glutamicum"

- Comparison of impedance flow cytometry with CFU analyses

- Cell viability measurements from sampling to results within five minutes

- Viability analyses of non-growing cultures

- Decreased viability in non-growing, glutamate producing cultures 